CLINICAL STUDY

\title{
An analysis of the biochemical diagnosis of 66 pheochromocytomas
}

\author{
Michèle d'Herbomez, Gérard Forzy ${ }^{1}$, Catherine Bauters ${ }^{2}$, Catherine Tierny ${ }^{3}$, Pascal Pigny ${ }^{3}$, Bruno Carnaille ${ }^{4}$, \\ François Pattou ${ }^{4}$, Jean-Louis Wémeau ${ }^{2}$ and Nathalie Rouaix ${ }^{3}$ \\ Department of Nuclear Medicine, CHRU, 59037 Lille, France, ${ }^{1}$ Laboratory of Biochemistry, Hospital Saint Philibert, 590160 Lomme, France, \\ Departments of ${ }^{2}$ Endocrinology, ${ }^{3}$ Biochemistry and ${ }^{4}$ Endocrine Surgery, CHRU, 59037 Lille, France
}

(Correspondence should be addressed to M d'Herbomez; Email: m-dherbomez@chru-lille.fr)

\begin{abstract}
Objectives: The aims of this study were to determine the performance of each variable, to define the optimal diagnostic thresholds and to determine the relative value of assaying chromogranin A $(\mathrm{CgA})$. Design: Prospective study.

Methods: Two groups of patients were studied: a control group of 71 patients and a group of 63 patients with a histologically-proven pheochromocytoma (52 pheochromocytomas and 14 paragangliomas). Fourteen of the patients had a family history of the disease. Eleven variables were assayed in each patient, i.e. the plasma and urinary concentrations of amines and their derivatives, and the $\operatorname{CgA}$ serum concentration.

Results: The study of the control group showed that all the serum assays gave false positive results (from 6 to $23 \%$ ), as did four of the six urinary assays (from 2.9 to $12.3 \%$ ). The areas under the receiver operating characteristic curves varied from 0.689 to 0.992 . The variables relating to the epinephrine pathway were significantly less expressed in the hereditary diseases than in the sporadic cases. The diagnostic thresholds of the three most efficient variables have been raised.

Conclusions: Plasma determinations of metanephrines are now an easy and convenient tool for the diagnosis of pheochromocytoma. However, in our study the best specificity was obtained with the urinary tests rather than with the plasma assays while the highest sensitivities were for the normetanephrine assays. The assay of $\mathrm{CgA}$ was highly efficient in diagnosing pheochromocytomas in the absence of renal insufficiency. By combining it with fractionated metanephrine assays, the sensitivities of the latter were increased.
\end{abstract}

European Journal of Endocrinology 156 569-575

\section{Introduction}

Pheochromocytomas and/or paragangliomas are rare, heterogeneous tumors of the chromaffin cells. They synthesize the catecholamines norepinephrine (NE), epinephrine (E) and more rarely dopamine (D), either singly or in combination. Their methoxylated metabolites (by the action of catechol-O-methyl-transferase), classified under the term of metanephrines, are normetanephrine NM, metanephrine $\mathrm{M}$, and 3-methoxytyramine 3Met respectively. The laboratory diagnosis of these tumors relies on the identification of excessive secretion of these catecholamines and/or of their derivatives. The need to be able to exclude a disease that can be fatal has led to several metabolic pathways being explored using various approaches (1-4). The first assays were those of urinary vanillylmandelic acid, of urinary catecholamines and total metanephrines (free and sulfur-conjugated) $(5,6)$, then those of plasma and urinary fractionated metanephrines (7-12) and most recently those of free plasma metanephrines (13-15). No variable on its own gives $100 \%$ precision (16). There is presently no consensus on the most reliable diagnostic method, providing the best quality/price ratio (17-19). Since 1998, assays of plasma fractionated metanephrines and of chromogranin $\mathrm{A}(\mathrm{CgA})$, a general indicator of neuroendocrine tumors that is highly expressed in pheochromocytomas, have been progressively widely developed and used (16, 20-28).

The aims of our study were to evaluate each variable in order to refine and simplify the test methodology, to adjust the decision-making thresholds and assess the relative value of the $\mathrm{CgA}$ assay.

\section{Materials and methods}

Two groups of patients were studied: a control group and a pheochromocytoma group. The control group consisted of 71 patients (41 women and 30 men) of 
average age 59 years who had been examined in the Endocrinology Department either for an adrenal growth that had been discovered by chance by scanner or abdominal sonography $(n=18)$, and/or who presented with clinical signs suggestive of a pheochromocytoma (some of these patients had suffered from primary $(n=18)$ or secondary $(n=13$, six with severe obesity) arterial hypertension). A diagnosis of pheochromocytoma was excluded in the controls by biology (all biological tests (catecholamines + metanephrines $+\mathrm{CgA}$ ) were in the normal range for 43 patients), by MIBG scintigraphies $(n=13$, all normal) and by the follow-up (range 4-6 years).

Sixty-three patients were included in the pheochromocytoma group ( 27 women and $36 \mathrm{men}$ ). The diagnoses were confirmed by anatomical/pathological examinations. All the patients had been surgically operated except one. Fifty-two patients had pheochromocytomas and fourteen paragangliomas. Three combinations of a pheochromocytoma and paraganglioma were detected. A hereditary history was revealed in $16(24 \%)$ of the patients. The inherited pheochromocytoma-associated syndromes are multiple endocrine neoplasia type $2(n=2)$ on account of mutations of the RET gene; von Hippel-Lindau disease (VHL, $n=7$ ) on account of mutations of the VHL gene; and the defined paraganglioma syndromes caused by mutations of the succinate dehydrogenase gene types B-D (SDHB $(n=3)$, $\operatorname{SDHC}(n=2)$, and $\operatorname{SDHD}(n=2))$. We described the genetic characterization in (29). We presented in these series two cases of SDHC mutation: the first a man with a bulky right tymporo-jugular paraganglioma (inextricable by surgery). The mutation was in the codon 158 (L158P). He was treated by radiotherapy and 131-MIBG. The second case, a man with inter-aortico-cave hormoneactive recurrent paraganglioma. The mutation was in the promoter $(\mathrm{c} .-38 \mathrm{G}>\mathrm{A})$. The mean age of the present patients was 49 years for the sporadic cases and 38 years for the hereditary ones. All patients have a normal renal function except two patients (one with pheochromocytoma and the other in the control group), who were at the upper limit of the normal range. The length of major axis of the tumor(s) was systematically recorded in the anatomical/pathological report.

Serum and urine samples were collected (for serum, after fasting and drug arrest such as $\alpha$ and/or $\beta$ blockers for minimum 3 days, a week or more where possible). The urinary results were corrected by the creatininuria value. The urinary assays of catecholamines and metanephrines were conducted on a $24 \mathrm{~h}$ urine sample, collected on $6 \mathrm{M}$ $\mathrm{HCl}\left(15 \mathrm{ml}\right.$ per $2 \mathrm{l}$ bottle) and were stored at $+4{ }^{\circ} \mathrm{C}$. After adjusting the urine to $\mathrm{pH} 6$, the free catecholamines (nonconjugated) were extracted on a cation-exchange resin (Chromsystems, Munich, Germany). The elution was conducted with $4 \%$ boric acid. Dihydroxybenzylamine was used as an internal standard.

The metanephrines were first hydrolyzed, in order to assay the total metanephrines (free and conjugated).
After adding $40 \mathrm{~g} / \mathrm{l}$ ammonium pentaborate to complex the catecholamines and adjusting the solution to $\mathrm{pH} 6-$ 7 , the extraction was conducted on the same cationexchange resin as previously, but this time the elution was conducted with $0.2 \mathrm{~mol} / \mathrm{l}$ ammonium acetate. 3-methoxy-4-hydroxybenzylamine was used as an internal standard.

The plasma assays of catecholamines and metanephrines were conducted on a blood sample collected onto lithium heparinate containing metabisulfite, after resting the patients in a supine position for $30 \mathrm{~min}$. The catecholamines were extracted on alumina (Chromsystems) with an elution by perchloric acid, and the metanephrines (after hydrolysis) on cation-exchange resin (Chromsystems).

The separation of urinary catecholamines and metanephrines and of plasma metanephrines was conducted by HPLC on a Hypersil ODS $5 \mu \mathrm{m}$ column (Alltech, Templemars, France) and on a Nova-Pak column (Waters, Guyancourt, France) for the plasma catecholamines. The detection was by coulometry, on a Coularray (ESA, Chelmsford, USA). We measured free+conjugated plasma metanephrines. The within-test coefficients of variation $(\mathrm{CV})$ were lower than $5 \%$, and the between-tests CVs were lower than $10 \%$ (respectively at 7.6 and $5 \%$ for a normetanephrine concentration to 6.1 and $34.4 \mathrm{nmol} / \mathrm{l}$ and 9.9 and $9.8 \%$ for a metanephrine level to 2.3 and $6.2 \mathrm{nmol} / \mathrm{l})$. The three catecholamines and the metanephrines were assayed together in the same operation. Reference values for the assays were established on mostly normotensive subjects. The cut-off levels of the laboratory were $47,14,290,260$ and $190 \mathrm{nmol} / \mathrm{mmol}$ creat for $\mathrm{NAu}, \mathrm{Au}, \mathrm{Du}, \mathrm{NMu}, \mathrm{Mu}$ respectively and 3.55, 0.44, 12.5, $3.4 \mathrm{nmol} / \mathrm{L}$ for NAp, Ap, NMp, Mp, $100 \mathrm{ng} / \mathrm{mL}$ for $\mathrm{CgA}$ assay. These are close to those recommended in the literature (5).

The serum concentrations of $\mathrm{CgA}$ were measured by radio-immuno assay (Ref CGA-RIA-CT; Schering, Gif-surYvette, France) in a prospective manner. This assay uses two monoclonal antibodies: one coated on the reaction tube, the other labeled with iodine 125. Recombinant human CgA was used as a standard. The free and bound phases were separated in the assay by suction. Normal values have been established as being $<100 \mathrm{ng} / \mathrm{ml}$ (23). The intratest coefficient of variation was $<5 \%$. The intertest coefficients were equal to 9.35 and $7.25 \%$ at concentrations of 100 and $370 \mathrm{ng} / \mathrm{ml}$ respectively $(n=$ $21)$. The $\mathrm{CgA}$ immunoreactant is stable.

The performances of various indicators were compared by analyzing the receiver operating characteristic (ROC) curves. The areas under the curves, considered to be the best quantitative indices, were calculated by a personal computer program. The values for the sporadic and hereditary groups were compared by the Mann-Whitney test. The sensitivities, specificities and positive and negative predictive values were calculated using standard formulae. 


\section{Results}

Table 1 summarizes the medians (ranges in brackets) for each parameter in controls, and in sporadic and hereditary diseases. On the basis of the laboratory reference values, all the five serum variables gave false positive results of $6-24 \%$, i.e., $7 \%$ for NAp, $8 \%$ for $\mathrm{Mp}$, $8 \%$ for $\mathrm{CgA}, 9 \%$ for Ap, and $24 \%$ for NMp. Four of the six urinary variables gave false positive results of $2.9-12.3 \%$, i.e., $2.9 \%$ for the Du assays, $4 \%$ for NAu, $6 \%$ for Metu ( $n=17$ only), and $12.3 \%$ for NMu.

For a more legible presentation, the ROC curves are shown in Fig. 1A and B. The three most efficient curves, for the variables $\mathrm{NMu}, \mathrm{NMp}$ and $\mathrm{CgA}$, are shown in Fig. 1A. The ROC curves for the other eight variables are shown in Fig. 1B. The areas under the curves were estimated to be 0.992 for $\mathrm{NMu}, 0.990$ for $\mathrm{NMp}$ and 0.988 for CgA. They were between 0.930 for NAu and 0.689 for $\mathrm{Du}$. In increasing order of their area under the curve, the variables could be ranked as follows: $\mathrm{Du}<\mathrm{Au}<\mathrm{Ap}<$ $\mathrm{Mp}<\mathrm{Mu}<3 \mathrm{Met}<\mathrm{NAp}<\mathrm{NAu}<\mathrm{CgA}<\mathrm{NMp}<\mathrm{NMu}$.

Moreover, we considered plasma norepinephrine and epinephrine as one single test. This should be done similarly for metanephrines. ROC curves for only five parameters are shown in Fig. 2. We found no significant differences between the five areas under the curves.

The distributions of the CgA, NMp concentrations in the controls and the patients with pheochromocytomas are shown in Figs 3 and 4. For a patient in the control group we observed an elevated CgA concentration due to omeprazole.

There were significant correlation coefficients between the length of the major axis of the tumor and all the biological variables except three (the assays of urinary, plasma noradrenaline and urinary adrenaline). The significances were between 0.02 and 0.05 for the assays of plasma adrenaline, between 0.01 and 0.02 for that of 3Metu, between 0.01 and 0.001 for $\mathrm{CgA}, \mathrm{Mu}$ and $\mathrm{Du}$ and $<0.001$ for the assays of plasma and urinary normetanephrine and plasma $\mathrm{M}$.

The comparison of the values for biological variables for sporadic and hereditary diseases is shown in Table 2. Significant differences were found for four variables (the assays of plasma and urinary epinephrine and metanephrines).

The sensitivity, specificity, negative, and positive predictive value for each variable and the positivity threshold are shown in Table 3.

\section{Discussion}

This study involved laboratory tests on 63 pheochromocytomas and/or paragangliomas conducted between 1998 and 2005 at a single center. Twenty-four percent of the patients presented with these diseases in a hereditary context, which is the generally accepted figure since genetic tests were developed $(29,30)$. Neuman et al. (30) found that on average hereditary pheochromocytomas were detected 14 years earlier than sporadic cases. We found a difference of 11 years. Hereditary pheochromocytomas can therefore be of a very small size $(<1 \mathrm{~cm})$ and difficult to detect.

Pheochromocytoma can be fatal and it is important to diagnose whilst the disease is still curable by surgery. The laboratory diagnosis of pheochromocytoma relies on demonstrating a hypersecretion of catecholamines and/or their derivatives (31). The use of plasma assays is more convenient for patients seen during consultations than collecting $24 \mathrm{~h}$ urine samples which are often incomplete. The urinary assays conducted after deconjugation reflect the conjugated forms produced by the tumor but also by other tissues. Recently, assays of free plasma metanephrines have been proposed in order to avoid false positives from free plus conjugated normetanephrines and metanephrines in cases of renal insufficiency. Free metanephrines reflect continuous production by the tumor in contrast to the sporadic secretion of catecholamines. Their measurement is probably little affected by sympathoadrenal stimulation. The measurement of such low concentrations can require the use of sophisticated equipment (mass spectrometry coupled to an HPLC system) which is only available in specialist centers. The results of urine tests expressed in relation to creatinine levels have shown less dispersion than those expressed in terms of the $24 \mathrm{~h}$ urinary output. We observed fewer moderately elevated values in the control group for the assay of

Table 1 Median values (ranges in brackets) of the various biological variables in the controls and in the sporadic and hereditary diseases (the urinary assays are expressed in $\mathrm{nmol} / \mathrm{mmol}$ creatinine, the plasma assays in $\mathrm{nmol} / \mathrm{l}$ and the chromograninA $(\mathrm{CgA})$ in $\mathrm{ng} / \mathrm{ml}$ ).

\begin{tabular}{lccc}
\hline & Controls $(n=71)$ & Sporadic diseases $(n=49)$ & Hereditary diseases $(n=14)$ \\
\hline NAp & $1.89(0.59-6.15)$ & $10.52(1.36-128.6)$ & $10.3(3.25-68.6)$ \\
Ap & $0.22(0-1.09)$ & $0.82(0-74.8)$ & $0.38(0-0.93)$ \\
NMp & $7.42(2.29-32.75)$ & $126.4(16.8-1299)$ & $76.7(9.3-704)$ \\
Mp & $2.44(0.41-512)$ & $23.8(0-779)$ & $3.5(0-134)$ \\
CgAp & $52(20-517)$ & $468(129-6880)$ & $374(93-1460)$ \\
NAu & $20.6(5.9-105)$ & $164.7(18.5-3447)$ & $278(32.5-1777)$ \\
$\mathrm{Au}$ & $3.1(0-11.2)$ & $20.3(0-1724)$ & $3.9(0-58.4)$ \\
NMu & $122.8(54-498)$ & $1492(291-17775)$ & $1413(169-8897)$ \\
Mu & $47.7(0-162)$ & $857.5(20.5-21665)$ & $69.8(22-5041)$ \\
3-Metu & $97.5(45.8-224.2)$ & $247.5(97.7-5694)$ & $253(82.9-887)$ \\
\hline
\end{tabular}



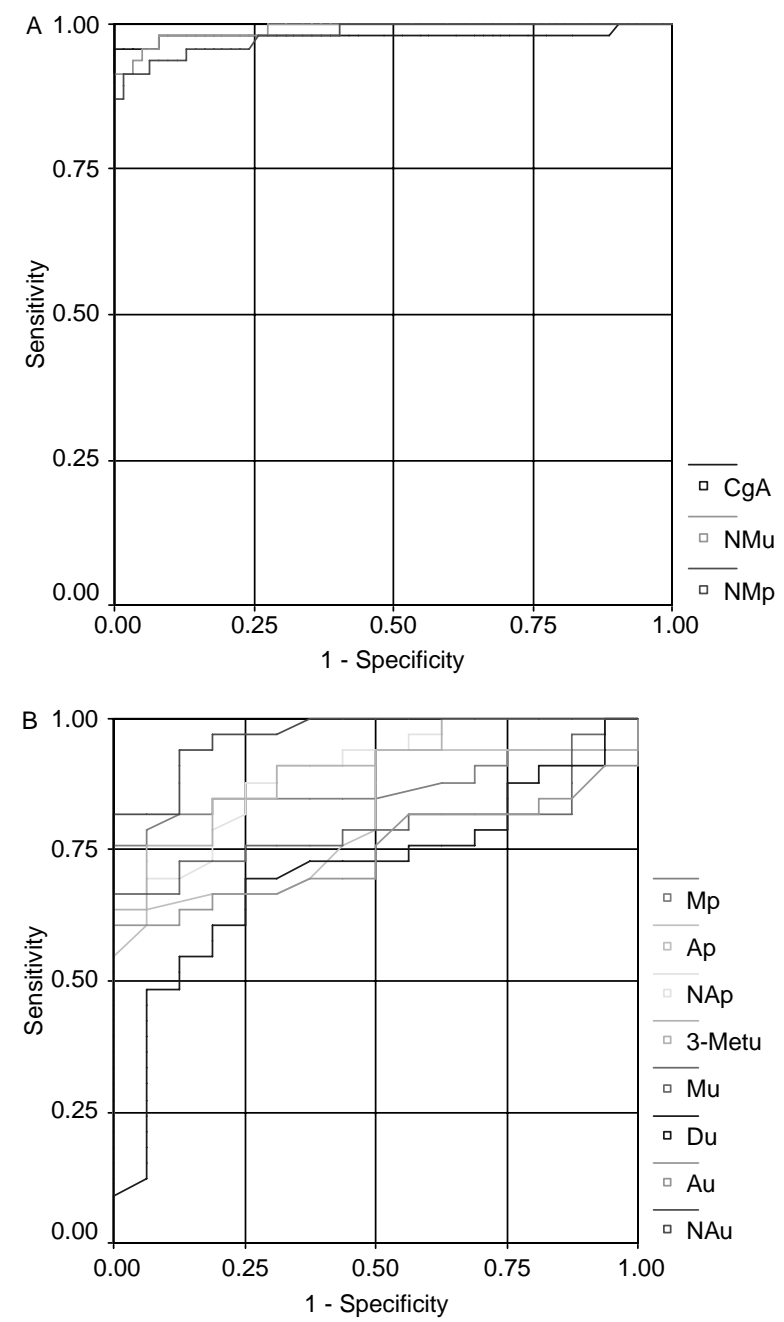

Figure 1 (A) ROC curves for the three better parameters $\mathrm{NMu}$, $\mathrm{NMp}$, and CgA. (B) ROC Curves for the eight other parameters.

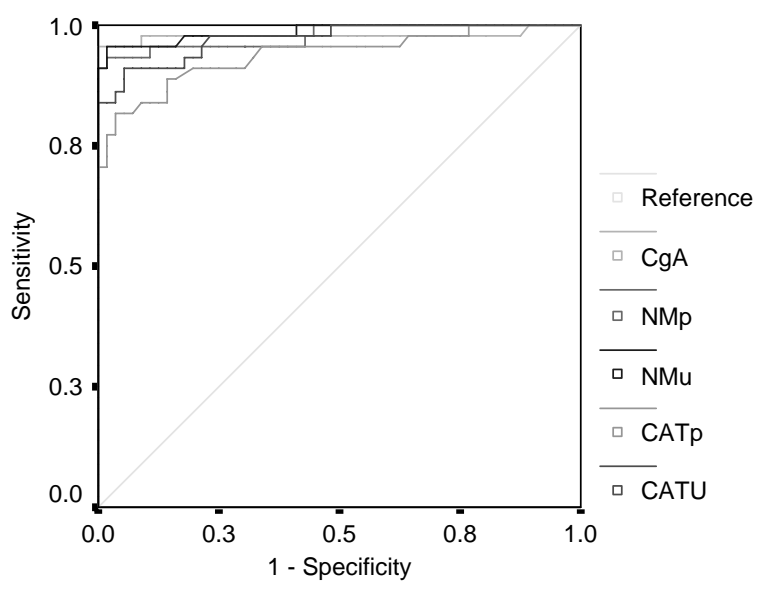

Figure 2 ROC Curves for only five parameters.

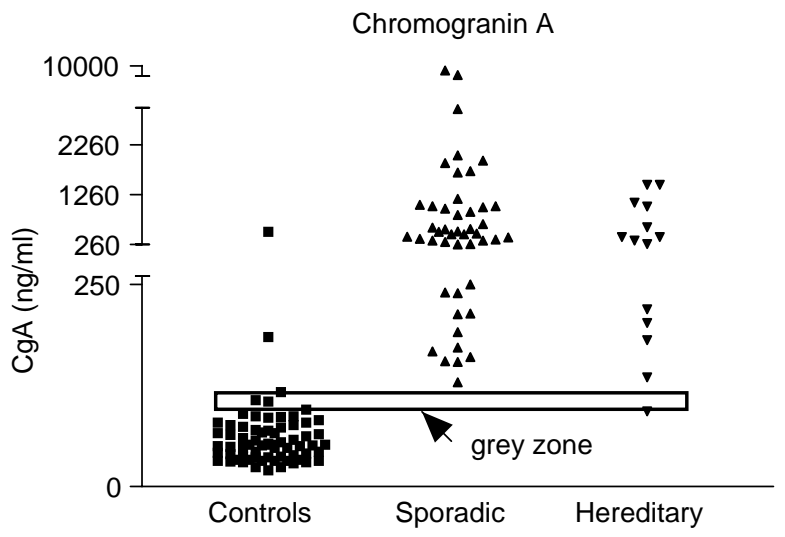

Figure 3 Distribution of the $\mathrm{CgA}(\mathrm{ng} / \mathrm{ml})$ in the controls and in the hereditary and sporadic pheochromocytomas.

urinary noradrenaline (4 and 25\%) and normetanephrine (12.3 and 29\%). This is presently the most favored method of presentation which we have used for the calculations.

The examination of the results of the assays in the control group revealed that five plasma variables gave false positive results, as did some urinary variables (four out of five). Two variables showed falsely high values, namely NMp (24\%) and NMu (12.3\%). It seems that the use of the thresholds of normality for these assays has certainly been under-estimated. There are many causes of interference that can either be varied or the same, depending on whether the assays are conducted on catecholamines, metanephrines, or $\mathrm{CgA}$. Three main causes of interferences in the assays that can explain the false positives encountered have been reported in the literature: diet, drug use and stress. For the assays of urinary and plasma catecholamines, taking cinnamic acid or its derivative dihydroxycinnamic acid (excellent substrates for the catechol O-methyltransferase) can cause elevated values. Many foods can contain sometimes

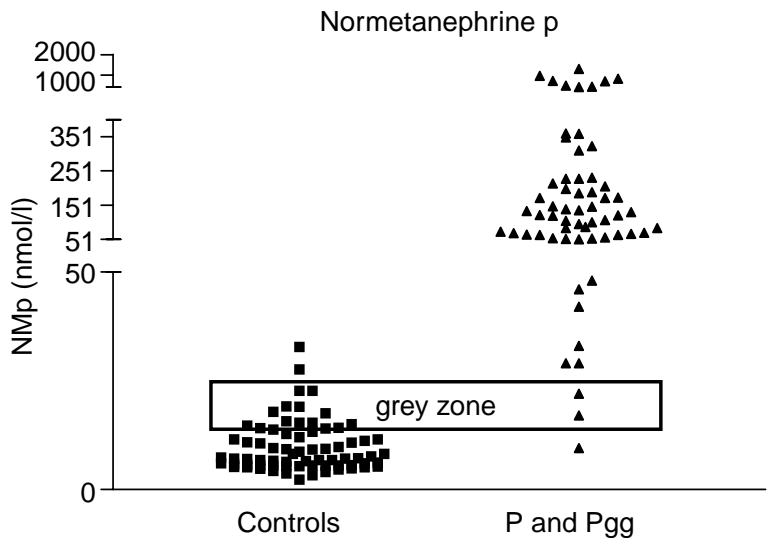

Figure 4 Distribution of the NMp concentrations in the controls and in the pheochromocytomas and paragangliomas. The black line corresponds with the cut-off level. 
Table 2 Mean values of the various biological variables recorded with hereditary and sporadic diseases (the urinary assays are expressed in $\mathrm{nmol} / \mathrm{mmol}$ creatinine, the plasma assays in $\mathrm{nmol} / \mathrm{l}$ and the $\mathrm{CgA}$ in $\mathrm{ng} / \mathrm{ml}$ ).

\begin{tabular}{lccc}
\hline & $\begin{array}{c}\text { Sporadic } \\
\text { diseases } \\
(n=49)\end{array}$ & $\begin{array}{c}\text { Hereditary } \\
\text { diseases } \\
(n=14)\end{array}$ & $\boldsymbol{P}$ \\
\hline NAp & 21.4 & 18.9 & 0.826 \\
Ap & 4.1 & 0.40 & 0.031 \\
Catecholamines $\mathrm{p}$ & 26.2 & 16.4 & 0.618 \\
NMp & 196.5 & 163.8 & 0.428 \\
Mp & 91.4 & 16.2 & 0.015 \\
Metanephrines $\mathrm{p}$ & 290 & 176 & 0.083 \\
CgAp & 892 & 561 & 0.354 \\
NAu & 387 & 520 & 0.199 \\
Au & 98 & 12.5 & 0.008 \\
Catecholamines u & 508 & 434 & 0.74 \\
NMu & 2960 & 2342 & 0.783 \\
Mu & 2026 & 575 & 0.010 \\
Metanephrines $\mathrm{u}$ & 4984 & 2857 & 0.24 \\
Du & 236 & 263 & 0.085 \\
3-Metu & $549(n=30)$ & $393(n=6)$ & 0.917 \\
\hline
\end{tabular}

unidentified substances that interfere with the HPLC assays. It is always best to collect plasma samples after fasting. Although the method for assaying urinary catecholamines and metanephrines has been described as being free from drug interferences (32-34), this problem is still presently being debated. For example, Eisenhofer's team admitted that they had 15\% false positives in their assays of free plasma metanephrines, half of which could be explained by taking medicines (35). According to them, the medicines most frequently blamed are tricyclic antidepressants, phenoxybenzamine and even paracetamol. Sawka et al. (36) reported 18\% false positives and thought that adjusting normetanephrine standards to the age of subjects could reduce the number of false positive values. Brain et al. (37) normalized values for urinary $24 \mathrm{~h}$ excretion of metanephrine and normetanephrine by dividing them by an age- and sex-specific reference range. Biausque et al. (38) encountered 15\%

Table 3 Sensitivity (Se), specificity (Spe), positive predictive value (PPV), negative predictive value (NPV) and cut-offs of the different biological parameters.

\begin{tabular}{lccccc}
\hline & Cut-off & Se (\%) & Spe (\%) & PPV (\%) & NPV (\%) \\
\hline NAp & 3.55 & 81.5 & 92.6 & 89.8 & 86 \\
Ap & 0.44 & 55.6 & 89.7 & 81.1 & 72 \\
NMp & 27 & 95.2 & 98.6 & 98.3 & 96 \\
Mp & 3.4 & 71 & 89.9 & 86.3 & 78 \\
CgAp & 120 & 98.3 & 97 & 96.7 & 98 \\
NAu & $<47$ & 83 & 97.1 & 95.6 & 88 \\
Au & $<14$ & 46.3 & 100 & 100 & 70 \\
Du & $<290$ & 24.1 & 97.1 & 86.7 & 62 \\
3-Metu & $<205$ & 61.1 & 94.1 & 95.6 & 53 \\
NMu & $<325$ & 96.2 & 96.9 & 96.2 & 97 \\
Mu & $<190$ & 50.9 & 100 & 100 & 72 \\
\hline
\end{tabular}

The urinary parameters are in $\mathrm{nmol} / \mathrm{mmol}$ creatinine, the plasma in $\mathrm{nmol} / \mathrm{l}$, and the CgA in $\mathrm{ng} / \mathrm{ml}$. false positives for the assay of $\mathrm{CgA}$ in patients recruited in a cardiology unit specializing in hypertension. Two thirds of the raised values were caused by renal insufficiency and the other third by taking proton pump inhibitors. These false positive results can lead to the unnecessary prescription of imaging such as MIBG scintigraphy or abdominal scans.

ROC curves provide an integrated comparison of sensitivities and specificities and can readily identify the most effective variables. The comparison of the various tests was conducted using the areas under the curves. The areas under the curves were between 0.992 for $\mathrm{NMu}$ and 0.689 for $\mathrm{Du}$, which illustrates great variability in the performance of the tests used. The classification into increasing order of performance clearly showed that whatever the metabolic pathway, the assays of metabolites were always shown to be better than those of the amines from which they are derived. This was the case for the assays of urinary and plasma metanephrines which were more efficient than those of urinary and plasma epinephrine, those of 3-methoxytyramine were better than those of urinary dopamine and those of normetanephrines were the most sensitive and specific. These results have been reported several times in the literature $(39,40)$ and in Fig. 2. Dopamine-secreting paragangliomas are extremely rare neoplasms that can only be diagnosed by the assay of plasma methoxytyramine (41). Overproduction of dopamine in patients with pheochromocytoma seems to be correlated with a higher risk of malignancy of hypotension. Moreover, dopamine secreting pheochromocytomas or metastasis often did not accumulate metaiodobenzylguanidine, thus failed to be detected and treated by $\left[{ }^{131}\right.$ I] MIBG.

To obtain the best sensitivities and specificities and to decrease the number of false positive results, we have raised the decision-making thresholds for the three bestperforming variables, by increasing these by $20 \%$ for $\mathrm{CgA}$ and by doubling them for the assays of plasma and urinary NMN. We have therefore fixed them at $120 \mathrm{ng} / \mathrm{ml}$ for $\mathrm{CgA}, 27 \mathrm{nmol} / \mathrm{l}$ for $\mathrm{NMNp}$ and $3820 \mathrm{nmol} / 24 \mathrm{~h}$ for $\mathrm{NMNu}$.

As with Sawka et al. (40) we found a better mean specificity with urinary assays $(98.2 \%$, range from 96.9 to $100 \%)$ than with plasma ones $(93.6 \%$, range from 89.7 to $98.6 \%$ ). This is valuable for the detection of pheochromocytomas in a sporadic context, where the best possible specificity is required. Like them, we also found a very good sensitivity for the plasma normetanephrine assay. These powerful tools allow pheochromocytomas and/or hereditary paragangliomas to be detected in the best possible conditions.

The use of a $\operatorname{CgA}$ assay in addition to those of catecholamines and/or metanephrines has been little studied in the literature. The publications are either old (24) or used an ELISA test with different immunoreactives from those we used (28). The reactive that we used had two monoclonal antibodies that recognize the 
central domain of the CgA molecule. This combination of antibodies detects most of the forms of $\mathrm{CgA}$ in the blood stream. In contrast, assays using antibodies directed against the median part of the molecule or against C-terminal epitopes will be more affected by proteolysis phenomena $(42,43)$. In this study, the assay of $\mathrm{CgA}$ showed excellent sensitivity and specificity in the absence of renal insufficiency. Its performance brought it into the top three best variables. Figure 3 clearly illustrates the distributions of concentrations in the controls and in the subjects with pheochromocytomas. We have confirmed that this general indicator of neuroendocrine tumors has a good reactivity in cases of both pheochromocytomas and paragangliomas. Its plasma concentration is proportional to the tumor mass (23) as is that of metanephrines. In our experience, it has been found lacking in hereditary contexts because these tumors can be very small in size. The main causes of interference in the CgA assay are renal insufficiency (27), followed by proton pump inhibitors or corticosteroids $(23,37)$. Renal insufficiency raises the $\mathrm{CgA}$ concentrations and those of metanephrines (44). The increase is correlated with the creatinine clearance rate. We also found the sensitivity and specificity reported in these conditions by Canale et al. (27). The excellent negative predictive value $(97 \%)$ of this variable is useful in cases of interference from medicines encountered in the assays of metanephrines. Tricyclic antidepressants such as phenoxybenzamine do not interfere in the assay of $\mathrm{CgA}$. In this study, the assay of $\mathrm{CgA}$ was a perfect back-up analysis. Its combination with the assays of fractionated metanephrine increased their sensitivity to $98.4 \%$. Using this combination, we obtained a sensitivity and specificity close to those of free plasma metanephrine assays. This easily-conducted plasma assay is an excellent early indicator of the urgency for surgical removal (23).

The epinephrine pathway is therefore less well expressed in the context of hereditary diseases. These results are in agreement with those of Eisenhofer et al. (45), who found an over-expression of the norepinephrine pathway in paragangliomas and in VHL disease. Half of our group hereditary disease group consisted of paragangliomas and five patients out of the fourteen had a mutation of VHL.

In conclusion, our study of eleven variables in the laboratory diagnosis of 66 pheochromocytomas and/or paragangliomas showed that it is important to carefully adjust the diagnostic thresholds of the most sensitive variables, that were shown to be assays of plasma and urinary normetanephrines and the $\mathrm{CgA}$. In our experience it appears that 1 ) the assays of metabolites were always more effective than those of the amines from which they are derived, 2) the urinary assays had a better specificity and 3) the serum assays provided better sensitivities specially when combined with the assay of $\mathrm{CgA}$.

\section{References}

1 Young WF Jr. Pheochromocytoma 1926-1993. Trends in Endocrinology and Metabolism 19934 122-127.

2 Lenders JW, Eisenhofer G, Manelli M \& Pacak K. Phaeochromocytoma. Lancet 2005366 665-675.

3 Mansmann G, Lau J, Balk E, Rothberg M, Miyachi Y \& Bornstein SR. The clinically inapparent adrenal mass: update in diagnosis and management. Endocrine Reviews 200425 309-340.

4 Yeo H \& Roman S. Pheochromocytoma and functional paraganglioma. Current Opinion in Oncology 200517 8-13.

5 Revol A, Comoy E, Forzy G, Garnier JP, Gerhardt MF, Hirth C, Jacob N, Mathieu P, Patricot MC,, Peyrin L, Diton A \& Ruedas E. Recommended methods for the determination of catecholamines and their metabolites in urine. Significance of results in the diagnosis and follow-up of pheochromocytoma and neuroblastoma. Annales de Biologie Clinique 199452 625-637.

6 Plouin PF, Chatellier G, Grouzmann E, Azizi M, Denolle T, Comoy E \& Corvol P. Plasma neuropeptide Y and catecholamine concentrations and urinary metanephrine excretion in patients with adrenal or ectopic phaeochromocytoma. Journal of Hypertension Supplement 19919 S272-S273.

7 Pagliari R, Cottet-Emard JM \& Peyrin L. Determination of free and conjugated normetanephrine and metanephrine in human plasma by high-performance liquid chromatography with electrochemical detection. Journal of Chromatography 1991563 23-36.

8 Lenders JW, Keiser HR, Goldstein DS, Willemsen JJ, Friberg P, Jacobs MC, Kloppenborg PW, Thien T \& Eisenhofer G. Plasma metanephrines in the diagnosis of pheochromocytoma. Annals of Internal Medicine 1995123 101-109.

9 Bravo EL. Plasma or urinary metanephrines for the diagnosis of pheochromocytoma? That is the question. Annals of Internal Medicine 1996125 331-332.

10 Kudva YC, Sawka AM \& Young WF Jr. Clinical review 164: the laboratory diagnosis of adrenal pheochromocytoma: the Mayo Clinic experience. Journal of Clinical Endocrinology and Metabolism 200388 4533-4539.

11 Raber W, Raffesberg W, Bischof M, Scheuba C, Niederle B, Gasic S, Waldhausl W \& Roden M. Diagnostic efficacy of unconjugated plasma metanephrines for the detection of pheochromocytoma. Archives of Internal Medicine $20001602957-2963$.

12 Eisenhofer G, Lenders JW, Linehan WM, Walther MM, Goldstein DS \& Keiser HR. Plasma normetanephrine and metanephrine for detecting pheochromocytoma in von HippelLindau disease and multiple endocrine neoplasia type 2. New England Journal of Medicine 1999340 1872-1879.

13 Lenders JW, Pacak K, Walther MM, Linehan WM, Mannelli M, Friberg P, Keiser HR, Goldstein DS \& Eisenhofer G. Biochemical diagnosis of pheochromocytoma: which test is best? JAMA 2002 287 1427-1434.

14 Weise M, Merke DP, Pacak K, Walther MM \& Eisenhofer G. Utility of plasma free metanephrines for detecting childhood pheochromocytoma. Journal of Clinical Endocrinology and Metabolism 200287 1955-1960.

15 Lagerstedt SA, O'Kane DJ \& Singh RJ. Measurement of plasma free metanephrine and normetanephrine by liquid chromatographytandem mass spectrometry for diagnosis. of pheochromocytoma. Clinical Chemistry 200450 603-611.

16 Bravo EL \& Tagle R. Pheochromocytoma: state-of-the-art and future prospects. Endocrine Reviews 200324 539-553.

17 Eisenhofer G, Walther M, Keiser HR, Lenders JW, Friberg P \& Pacak K. Plasma metanephrines: a novel and cost-effective test for pheochromocytoma. Brazilian Journal of Medical and Biological Research 200033 1157-1169.

18 Sawka AM, Gafni A, Thabane L \& Young WF Jr. The economic implications of three biochemical screening algorithms for pheochromocytoma. Journal of Clinical Endocrinology and Metabolism $2004892859-2866$.

19 Sawka AM, Prebtani AP, Thabane L, Gafni A, Levine M \& Young WF Jr. A systematic review of the literature examining the 
diagnostic efficacy of measurement of fractionated plasma free metanephrines in the biochemical diagnosis of pheochromocytoma. BioMed Central Endocrine Disorders 200442.

20 O'Connor DT \& Deftos LJ. Secretion of chromogranin A by peptideproducing endocrine neoplasms. New England Journal of Medicine $19863141145-1151$.

21 Taupenot L, Harper KL \& O'Connor DT. The chromograninsecretogranin family. New England Journal of Medicine $2003 \mathbf{3 4 8}$ 1134-1149.

22 Nobels FR, Kwekkeboom DJ, Coopmans W, Schoenmakers CH, Lindemans J, De Herder WW, Krenning EP, Bouillon R \& Lamberts SW. Chromogranin A as serum marker for neuroendocrine neoplasia: comparison with neuron-specific enolase and the alpha-subunit of glycoprotein hormones. Journal of Clinical Endocrinology and Metabolism 199782 2622-2628.

23 d'Herbomez M, Gouze V, Huglo D, Nocaudie M, Pattou F, Proye C, Wemeau JL \& Marchandise X. Chromogranin A assay and (131)IMIBG scintigraphy for diagnosis and follow-up of pheochromocytoma. Journal of Nuclear Medicine 200142 993-997.

24 Hsiao RJ, Neumann HP, Parmer RJ, Barbosa JA \& O'Connor DT. Chromogranin A in familial pheochromocytoma: diagnostic screening value, prediction of tumor mass, and post-resection kinetics indicating two-compartment distribution. American Journal of Medicine $1990 \mathbf{8 8} 607-613$.

25 Bernini GP, Moretti A, Ferdeghini M, Ricci S, Letizia C, D’Erasmo E, Argenio GF \& Salvetti A. A new human chromogranin 'A' immunoradiometric assay for the diagnosis of neuroendocrine tumours. British Journal of Cancer 200184 636-642.

26 Bernini G, Moretti A, Fontana V, Orlandini C, Miccoli P, Berti P, Basolo F, Faviana P, Bardini M \& Salvetti A. Plasma chromogranin A in incidental non-functioning, benign, solid adrenocortical tumors. European Journal of Endocrinology $2004151215-222$.

27 Canale MP \& Bravo EL. Diagnostic specificity of serum chromogranin-A for pheochromocytoma in patients with renal dysfunction. Journal of Clinical Endocrinology and Metabolism $1994 \mathbf{7 8}$ 1139-1144.

28 Van de Herder WW, de Krijger RR, Bruining HA, Bonjer HJ, Lamberts SW, Van den Meiracker AH, Stijnen TH \& Boomsma F. The value of plasma markers for the clinical behaviour of phaeochromocytomas. European Journal of Endocrinology 2002 147 85-94.

29 Bauters C, Leclerc L, Wemeau JL, Proye C, Pigny P \& Porchet N. Multiple endocrine neoplasias. Recent advances in clinical and genetic diagnosis. Revue de Medecine Interne 200324 721-729.

30 Neumann HP, Berger DP, Sigmund G, Blum U, Schmidt D, Parmer RJ, Volk B \& Kirste G. Pheochromocytomas, multiple endocrine neoplasia type 2, and von Hippel-Lindau disease. New England Journal of Medicine 1993329 1531-1538.

31 Candito M, Billaud E, Chauffert M, Cottet-Emard JM, Desmoulin D, Garnier JP, Greffe J, Hirth C, Jacob N, Millot F, Nignan A, Patricot MC, Peyrin L \& Plouin PF. Biochemical diagnosis of pheochromocytoma and neuroblastomas. Annales de Biologie Clinique $20026015-36$.

32 Wassell J, Reed P, Kane J \& Weinkove C. Freedom from drug interference in new immunoassays for urinary catecholamines and metanephrines. Clinical Chemistry 199945 2216-2223.
33 Kushnir MM, Rockwood AL, Nelson GJ, Yue B \& Urry FM. Analysis of catecholamines in urine by positive-ion electrospray tandem mass spectrometry. Clinical Chemistry 200248 323-331.

34 Taylor RL \& Singh RJ. Validation of liquid chromatographytandem mass spectrometry method for analysis of urinary conjugated metanephrine and normetanephrine for screening of pheochromocytoma. Clinical Chemistry 200248 533-539.

35 Eisenhofer G, Goldstein DS, Walther MM, Friberg P, Lenders JW, Keiser HR \& Pacak K. Biochemical diagnosis of pheochromocytoma: how to distinguish true- from false-positive test results. Journal of Clinical Endocrinology and Metabolism 200388 2656-2666.

36 Sawka AM, Thabane L, Gafni A, Levine M \& Young WF Jr. Measurement of fractionated plasma metanephrines for exclusion of pheochromocytoma: can specificity be improved by adjustment for age? BioMed Central Endocrine Disorders 2005281.

37 Brain KL, Kay J \& Shine B. Measurement of urinary metanephrines to screen for pheochromocytoma in an unselected hospital referral population. Clinical Chemistry 200652 2060-2064.

38 Biausque F, Jaboureck O, Devos P, D'Herbomez M, Hainaut P, Carre A \& Mounier-Vehier C. Clinical significant of serum chromogranin A levels for diagnosing pheochromocytoma in hypertensive patients. Archives des Maladies du Coeur et des Vaisseau 200396 780-783.

39 Sawka AM, Jaeschke R, Singh RJ \& Young WF Jr. A comparison of biochemical tests for pheochromocytoma: measurement of fractionated plasma metanephrines compared with the combination of 24-hour urinary metanephrines and catecholamines. Journal of Clinical Endocrinology and Metabolism 200388 553-558.

40 Unger N, Pitt C, Schmidt IL, Walz MK, Schmid KW, Philipp T, Mann K \& Petersenn S. Diagnostic value of various biochemical parameters for the diagnosis of pheochromocytoma in patients with adrenal mass. European Journal of Endocrinology 2006154 409-417.

41 Eisenhofer G, Goldstein DS, Sullivan P, Csako G, Brouwers FM, Lai EW, Adams KT \& Pacak K. Biochemical and clinical manifestations of dopamine-producing paragangliomas: utility of plasma methoxytyramine. Journal of Clinical Endocrinology and Metabolism $2005902068-2075$.

42 Stridsberg M \& Husebye ES. Chromogranin A and chromogranin B are sensitive circulating markers for phaeochromocytoma. European Journal of Endocrinology 1997136 67-73.

43 Degorce F, Goumon Y, Jacquemart L, Vidaud C, Bellanger L, PonsAnicet D, Seguin P, Metz-Boutigue MH \& Aunis D. A new human chromogranin A (CgA) immunoradiometric assay involving monoclonal antibodies raised against the unprocessed central domain (145-245). British Journal of Cancer 199979 65-71.

44 Grossrubatscher E, Dalino P, Vignati F, Gambacorta M, Pugliese R, Boniardi M, Rossetti O, Marocchi A, Bertuzzi M \& Loli P. The role of chromogranin A in the management of patients with phaeochromocytoma. Clinical Endocrinology 200665 287-293.

45 Eisenhofer G, Huysmans F, Pacak K, Walther MM, Sweep FC \& Lenders JW. Plasma metanephrines in renal failure. Kidney International $200567668-677$.

Received 24 October 2006

Accepted 5 February 2007 